\title{
Osteogenesis imperfecta: the role and place of orthopedic surgery of the lower extremities
}

\author{
D.A. Popkov ${ }^{1}$, E.R. Mingazovi1, A.V. Gubin², N.S. Gvozdev ${ }^{1}$, A.M. Aranovich ${ }^{1}$, A.L. Semenov ${ }^{3}$ \\ ${ }^{1}$ Ilizarov National Medical Research Centre for Traumatology and Orthopedics, Kurgan, Russian Federation \\ ${ }^{2}$ National Medical Research Center of Traumatology and Orthopedics n.a. N.N. Priorov, Moscow, Russian Federation \\ ${ }^{3}$ Novosibirsk Research Institute of Traumatology and Orthopaedics N.a. Ya.1. Tsivyan, Novosibirsk, Russian Federation
}

\begin{abstract}
Introduction Surgical correction of orthopedic problems in children and adults with severe osteogenesis imperfecta is of interest to the medical community. The aim of this study was to review the current relevant literature on the role of orthopedic surgery in the treatment of children and adults with osteogenesis imperfecta and the integration of surgery into a multidisciplinary approach to the treatment of patients with osteogenesis imperfecta. The review is based on the material of the report presented at the first educational conference of the European Pediatric Orthopedic Society which was held in Russia at the Ilizarov Center in 2021. Material and methods To prepare the review, we searched for information sources at the scientific platforms such as PubMed, Scopus, ResearchGate, RSCI, as well as published products (Elsevier, Springer). Results and discussion The review includes a discussion of the classification, indications, features of the surgical technique and the early postoperative period, the role of early functional loading, the features of long-term treatment results of using telescopic transphyseal constructs in the correction of deformities of lower limb long bones as well as issues of the combination of orthopedic surgery and bisphosphonate therapy. Conclusion Orthopedic support of children and adults with severe and moderate types of osteogenesis imperfecta requires construction of a multifactorial strategy that takes into account the requirements of physical therapy and medication treatment, as well as the use of specialized implants, instrumentation and methods of surgical intervention, while an optimal solution has been still sought.
\end{abstract}

Keywords: osteogenesis imperfecta, deformity correction, telescopic nail

\section{INTRODUCTION}

Surgical correction of orthopedic problems in children and adults with severe types of osteogenesis imperfecta evokes an increasing interest in the medical community. The aim of this study was to review the current relevant literature on the role of orthopedic surgery in the treatment of children and adults with osteogenesis imperfecta and the integration of surgery into a multidisciplinary approach in the treatment of patients with osteogenesis imperfecta. The review is based on the material presented at the educational conference of the European Pediatric Orthopedic Society held in Russia at the Ilizarov Center for the first time in 2021, which is presented by sections.

\section{MATERIAL AND METHODS}

To prepare the review, we searched for information sources at the scientific platforms such as PubMed,
Scopus, ResearchGate, RSCI, as well as other published products (Elsevier, Springer).

\section{RESULTS AND DISCUSSION}

\section{Definition}

Osteogenesis imperfecta (OI) is a group of genetic disorders caused by different inherited mutations and is characterized by frequent fractures, bone deformities, low bone mineral density and osteopenia [1-5].

Clinical and radiographic classification

The first clinical classification of OI was proposed by Sillence et al in 1979 [1]. It is based on clinical and radiological manifestations of the disease and distinguishes types I, II, III and IV of the disease, as mentioned above. Subsequently, the classification was expanded [3, 4]; in particular, type $\mathrm{V}$ was added (dominantly inherited OI with the formation of bulky hypertrophied calluses not prone to remodeling and ossification of the interosseous membranes). However, the generally accepted classification of osteogenesis imperfecta has not been developed yet [6]. Currently, for clinical purposes associated with the surgical correction of orthopedic problems in OI (choice of method, prognosis), despite the progress in genetic studies and the identification of new genes responsible for the disease, the phenotypic (clinical and radiological) classification remains relevant $[9,10]$. The Working Group of the International Skeletal Dysplasia Society recommends identifying the type of OI (I, II, III, IV, V) by clinical signs, defining subclasses depending on the type of inheritance and the genetic abnormality found $[7,11]$. 
The decision on the method of surgical treatment is made on the basis of disease severity identified with a modified Sillence classification [9, 10]. Clinical and radiological classification [9] is used for purely practical purposes. Type I refers to a mild course of the disease, characterized by a relatively low frequency of fractures and a low risk of bone deformities, and rare indications for reconstructive treatment. Type II is the most severe OI type; children die at an early age, indications for surgical orthopedic treatment are not considered. Type III is the most severe type of OI in children who have survived the neonatal period, and in whom the frequency of fractures and deformities is high. Type IV is characterized as moderately severe or moderate; fractures and deformities are more common than in the first type, indications for surgical treatment are very frequent. Type $\mathrm{V}$ is of similar severity to type IV but the formation of volumetric hypertrophied and not prone to remodeling calluses after fractures and osteotomies along with ossification of the interosseous membranes significantly limit the indications for surgical treatment.

\section{Conservative orthopedic treatment}

Conservative orthopedic treatment, in fact, is part of a physical therapy program aimed at maintaining the child's physical activity, acquiring skills in vertical posture, maintaining and developing muscle strength $[7,8,12-14]$.

Orthoses applied on the lower extremities (tutors, apparatuses) aim to compensate for joint instability associated with hyperelasticity of the ligamentous apparatus, and to correct the position in the joints due to muscle weakness, which is also part of the program of postoperative management of patients [13, 14].

Limb fracture repair in children with osteogenesis imperfecta

The choice of treatment method depends, first of all, on the type and severity of osteogenesis imperfecta.

In OI type I, bone consolidation occurs within the usual term. And, if surgical treatment involving internal osteosynthesis does not find indications, the duration of immobilization with a plaster cast should not be longer than in healthy children $[8,11]$.

In severe OI types (types III, IV), an increased rate of fractures is observed in the preschool and school age $[15,16]$. The principal approach to treatment is to minimize duration of immobilization and the period without functional limb loading in order to exclude the development of secondary osteoporosis [8, 17-19].

Almost complete elimination of the displacement of fragments is mandatory, since the consolidation of fractures with angular deformities of more than $20^{\circ}$ predisposes to repeated pathological fractures due to pathological restructuring of the bone tissue in the deformed portion of the bone [20-22]. For treating fractures due to existing deformities, it is recommended to perform primary telescopic intramedullary osteosynthesis in combination with surgical correction of angular and torsional deformities [10, 12, 16, 17, 23-29]. The primary use of telescopic intramedullary osteosynthesis reduces the frequency of future interventions in comparison with the osteosynthesis with traditional non-telescopic implants [30].

Fixation with plates or screws is contraindicated in osteosynthesis in OI patients, since stress concentration of efforts leads to bone fractures at the border of the materials with different mechanical properties, at the level of the proximal and distal edges of the plate [8,31-33].

It should be noted that the use of non-telescopic structures (Kirschner wires, Kuntcher nails, Rush or Ender rods) in the treatment of bone fractures provides good and excellent results in the short term. However, as the bone grows and the growth plates move from the osteosynthesis site, problems of fractures and progressive deformities arise in the newly formed bone areas, outside the osteosynthesis zone [11, 17].

Long-bone deformity correction in children with OI

The global task of orthopedic surgical treatment of deformities as part of a multidisciplinary approach is to maintain physical activity, autonomy, the ability to acquire and develop motor skills, and facilitate care. This is achieved through an increase in the mechanical strength of bones throughout their entire length by surgical intervention, prevention of recurrence of deformities and a decrease in the frequency of fractures $[10,11,14,34]$.

The optimal moment for surgical correction is the age when the child is physiologically ready for vertical posture and walking $[8,29,30]$.

The indications for surgical treatment in children, which most orthopedists recognize as reasonable, are angular deformities of the lower extremities of more than $20^{\circ}$, deformities of a progressive nature, repeated fractures, more often localized on the deformity arch, functional motor disorders caused by torsion deformities, bone nonunion, varus deformity of the neck of the femur accompanied by a significant limitation of hip abduction, absence or loss of skills of independent movement or even vertical positioning due to frequent fractures even in case of minor deformities of the limbs, when orthopedic treatment with orthoses is ineffective [4, 35-38].

The generally accepted methods of correcting bone deformities are corrective osteotomies while the main method of osteosynthesis is telescopic intramedullary rigid or elastic rods in the medullary canal with the diverging parts of the rods in opposite epiphyses (apophyses), distal and proximal to growth zones $[11,12,17,19,25,26,28]$. They ensure constant reinforcement of the bone throughout the 
entire process of growth due to the divergence of the parts of the structure in opposite directions [25, 39].

Modern telescopic systems enable their extraarticular introduction by performing minimally invasive percutaneous osteotomies, preserve the periosteal blood supply to the bone, reduce the time and invasiveness of the operation, and also minimize the complications inherent in open surgical interventions. The FassierDuval rod [26, 39, 40], the Sheffield rod [41] and its modifications [42], the Santili telescopic intramedullary rod [43], and the Russian titanium telescopic rod [28, 44] have been used in surgical practice. Telescopic systems providing sliding of one part inside another have been currently the method of choice. Their use in children with severe and moderate OI types provides an improvement in functional abilities, increased motor activity, autonomy, a decrease in the number of reoperations and a decrease in the number of fractures $[10,30]$. The decreased invasiveness of the intervention allows for simultaneous bilateral reinforcement of the femur in children with OI type III [10].

Transphyseal reinforcement with elastic nails retains indications for small transverse diameters of bones (especially at the age of 4-5 years), with complete obliteration of the medullary cavity and small diameters, when the nails may pass subperiosteally, as well as for correction of forearm deformities [25, 45-47]. Subperiosteal conduction of elastic nails at the level of the diaphysis, inserted transphyseally and from the metaphysis into the opposite metaphyseal part, has been indicated in complete obliteration of the medullary canal, a small diameter of the bone, in children under 6 years of age in case if technical implementation of the reinforcement with telescopic rods is impossible [48].

If there are indications, the reinforcement with elastic nails or Rush rods is technically possible already from the age of 2-3 years; the use of telescopic rods is recommended (primary or secondary with the replacement of the previously installed thin rods and pins) as soon as the diameter of the bone and the transverse dimensions of the medullary canal allow this to be done technically $[10,17,26,30,40]$.

The use of external osteosynthesis for lengthening or gradual correction of deformities is possible only in patients with OI of mild severity (type I) or in combination with intramedullary osteoinductive osteosynthesis. The latter possibility has so far been presented only in some cases $[49,50]$.

At the present stage, the use of telescopic systems in comparison with conventional means of intramedullary osteosynthesis remains somewhat controversial. Telescopic systems are more difficult to use and much more expensive [51]. Moreover, telescopic systems have the risk of failure of separation of their parts and damage to the growth cartilage that means the loss of their function [8].

\section{Complications and repeated interventions in} telescopic nailing

Information on the risks associated with complications and re-interventions should be fully communicated to the family members of the patient. The medical and patient community must be ready that there are risks even with the use of a sufficiently high level of surgical technology.

The total rate of repeated interventions, including rod change as the child grows and surgical correction of complications if telescopic rods are used throughout the child's growth is $14.3-53 \%$; by using non-telescopic implants it is $58-87 \%$, and up to $100 \%$ of cases in elastic reinforcement $[8,27,40$, $52,53]$. The Canadian team reported a $36.1 \%$ rate of reoperations and rod changes over a follow-up period of more than 10 years, but the results were reported as a presentation [54].

In the peer-reviewed publications, the following data can be found. Retention of position and effectiveness of the Fassier-Duval rod (survival without replacing the rod with a new one) for the three-year period was $92.3 \%$ [30], $77 \%$ for Bailey-Dubow [55] and $92.9 \%$ for the Sheffiel telescopic Rod [56]. Azzam et al reported Fassier-Duval rod replacement in $53 \%$ of cases within 52 months after surgery [52]. Cho et al [57] for a modified Sheffield rod and Spahn et al [30] for the Fassier-Duval rod indicate an $88 \%$ survival rate over a four-year period. Finally, for a five-year period without replacing the rod for a new one, the result of the operation was retained in $63 \%$ for the thigh and $64 \%$ for the lower leg according to Cox et al [58]. Shin et al used a dual interlocking telescopic rod (D-ITR) and reported that after an average followup of 5.3 years the need to replace the rod was seen in $25 \%$ of cases, which is the best result among all known telescopic systems [42].

In terms of the greatest balance between the number of operations, recurrence of deformities and their surgical correction, and the achieved result, the methods of acute correction of deformities with transphyseal reinforcement in children in combination with external fixation (2.1 surgeries per case, on average, for a follow-up period of 2 or more years) are comparable with the data of the isolated use of elastic transphyseal reinforcement (2.5 operations per case) [25, 27], but higher than for a telescopic rod [12, 26, 27, 33].

Moreover, the rate of revision surgery also depends on the severity of OI and it reaches $67.86 \%$ in OI type III and $31.82 \%$ in OI type IV[43].

Non-divergence of the telescopic rod parts (2.1$40 \%$ of cases), intra-articular displacement of the ends of the rod and migration of parts of the implant $(2.1-12.7 \%)$, fractures and deformations of the rod (up to $6.9 \%$ ), bone fractures on the rod (up to $27 \%$ ) are found, in general, in 35-40\% of cases with the use of telescopic rods in patients with severe and moderate OI 
types [11, 26]. Boutaud et al reported a $25 \%$ incidence of complications with elastic reinforcement but for a series where $42.9 \%$ of patients were with OI type I [25].

The incidence of nonunion or delayed consolidation at the osteotomy level varies from 0 to $14.5 \%$ [26, 40]. Munns et al observed delayed bone consolidation in 103 cases out of $200(51.5 \%)$ treated with the Fassier-Duval rod, which was typical in patients with OI type IV after the operations on the lower leg bones who received pamidronate [59].

The eccentric position of the inner part of the Fassier-Duval rod in the distal epiphysis (technical errors) significantly increases the risks of nondivergence of the rod parts, its bending, loss of fixation in the epiphyses and the need for its replacement [60]. The authors of this publication in 13 patients who were treated with 66 Fassier-Duval rods and sustained 75 operations during a follow-up period of 8.9 years, encountered the following complications: loss of rod fixation in the epiphyses or greater trochanter (6 cases), lack of telescoping (7 cases), protrusion of the rod into the joint (12 cases), significant bending of the rod (6 cases) that required revision intervention.

The isolated use of intramedullary implants requires from 4 to 8 weeks in the postoperative period without loading. This is an unfavorable condition as it contributes to an additional decrease in bone density $[25,36,61,62]$.

Telescopic rods and elastic intramedullary reinforcement do not at all prevent the occurrence of secondary torsional deformations. At the level of the femur, retroversion of the neck is typical which is clinically expressed by a pronounced external rotation of the entire limb [36, 37, 63, 64].

The combination of a telescopic rod and external osteosynthesis which is limited in time and volume allows axial load on the operated limb during the first week after surgery and completely eliminates secondary torsion and longitudinal displacement of bone fragments [26, 28, 65]. In a series of 12 patients with a relatively short follow-up period of 1-3 years, the safety of the use of a limited (in time and volume) external osteosynthesis for patients with osteogenesis imperfecta was shown. There was not a single case of non-divergence of the parts of the titanium rod or its deformities associated with specific features of the alloy from which it was made [28].

Another way to prevent secondary torsional deformations is the combined use of telescopic rods and locking plates with monocortical screw insertion in some cases [66]. However, this method of shunting the axial forces with a plate eliminates the load on the operated area of the bone but requires a mandatory separate operation to remove the plate after bone consolidation [66]. And, of course, such a method of osteosynthesis excludes the possibility of minimally invasive percutaneous osteotomies, which are possible with the installation of a Fassier-Duval telescopic rod $[26,39]$. Preliminary results of the use of plate fixation of the fracture site or osteotomy in combination with telescopic or non-telescopic rods showed that after a follow-up period of 10 months, bone union occurred after a mean period of 8.8 weeks [67].

There is a risk of epiphysiodesis as a complication of transphyseal implants application [8, 11, 17]. Currently, the magnitude of this risk has not been studied in clinical settings.

The use of steel implants limits or completely excludes the use of MRI in children with OI in situations if indicated [68-70]. The only publication based on a retrospective series of 10 cases (evidence level IV) provides the possibility of performing MRI of no more than $1.5 \mathrm{~T}$ in patients with Fassier-Duval steel rods, but indicates a limitation of the significance of these results due to a small sample, lack of data in performing MRI on more powerful systems (more than $1.5 \mathrm{~T}$ ) and, accordingly, the need to warn patients and their parents about the theoretical risk of migration of steel rods [71]. The use of titanium rods prevents problems with magnetic resonance imaging [44].

Orthopedic interventions in adults with $\mathrm{OI}$

Typical orthopedic problems in adults with osteogenesis imperfecta include fractures, deformities, and early degenerative changes in the joints [72-74].

Conservative treatment is recommended for closed fractures without displacement [60]. Osteosynthesis should not be performed with plates or rigid rods [72].

There is a high risk of nonunion or delayed consolidation by performing reconstructive surgery, $[72,73]$. The use of combined techniques in association with osteoinductive intramedullary rods reduces the risk of nonunion [44]. Arthroplasty is based on the use of customized joint implants [8].

Orthopaedic surgery and bisphosphonate therapy

There is limited evidence of the effectiveness of bisphosphonates in reducing the incidence of long bone fractures in children in a controlled randomized trial [75]. Meta-analysis of the literature and two Cocrane reviews do not support a positive effect of bisphosphonates on the incidence of fractures in children with osteogenesis imperfecta [76-78].

The use of bisphosphonates does not slow down the healing of bone fractures $[11,78,79]$. There is a risk [80-82] of pathological fractures at the level of areas of increased bone density due to inhibition of bone remodeling and a decrease in the elastic properties of bone tissue as a result of excessive intake of bisphosphonates.

The risk of delayed bone union after corrective osteotomies, performed not with a vibrating saw but with an osteotome, is reduced by taking a 4-month break in bisphosphonates intake (zoledronic acid and pamidronate) $[59,83]$. 
Intake of bisphosphonates reduces the amount of blood loss in surgical correction of deformities due to effect of increasing bone density, reducing the proportion of cancellous bone substance, thickening of the cortical plates. On the other hand, the inhibiting the effect of bisphosphonates on farnesyl pyrophosphate synthetase and prenylation of many plasma proteins, including methylenetetrahydrofolium, is able to disturb the coagulation cascade [84].
It was reported that administration of pamidronate resulted in the absence of consolidation one year after the operation in $72 \%$ of cases. When this drug was changed to zoledronic acid in the therapeutic protocol, the infusion of which was started no earlier than 4 months after the operation, it reduced the incidence of nonunion to $42 \%$. Moreover, the performance of osteotomy without the use of a vibrant saw but with an osteotome has been also attributed to the factors that improve the conditions for bone consolidation $[59,83]$.

\section{CONCLUSION}

Orthopedic support of children and adults with severe and moderate types of osteogenesis imperfecta requires construction of a multifactorial strategy that should consider the requirements of physical therapy and medication treatment, as well as the use of specialized implants, instrumentation and methods of surgical intervention, while an optimal solution has been still sought.

\section{REFERENCES}

1. Sillence D.O., Senn A., Danks D.M. Genetic heterogeneity in osteogenesis imperfecta. J. Med. Genet., 1979, vol. 16, no. 2, pp. 101-116. DOI: 10.1136/jmg.16.2.101.

2. Cheung M.S., Glorieux F.H. Osteogenesis imperfecta: update on presentation and management. Rev. Endocr. Metab. Disord., 2008, vol. 9, no. 2, pp. 153-160. DOI: 10.1007/s11154-008-9074-4.

3. Van Dijk F.S., Pals G., Van Rijn R.R., Nikkels P.G., Cobben J.M. Classification of osteogenesis imperfecta revisited. Eur. J. Med. Genet., 2010, vol. 53, no. 1, pp. 1-5. DOI: 10.1016/j.ejmg.2009.10.007.

4. Glorieux F.H. Osteogenesis imperfecta. Best Pract. Res. Clin. Rheumatol., 2008, vol. 22, no. 1, pp. 85-100. DOI: 10.1016/j.berh.2007.12.012.

5. Kostik M.M., Chikova I.A., Buchinskaia N.V., Kalashnikova O.V., Marycheva N.M., Asanov A.Iu., Shchepliagina L.A., Larionova V.I. Opyt terapii bisfosfonatami detei s nesovershennym osteogenezom [Experience of therapy with bisphosphonates in children with osteogenesis imperfecta]. Lechenie i Profilaktika, 2014, vol. 3, no. 11, pp. 13-20. (in Russian)

6. Forlino A., Marini J.C. Osteogenesis imperfecta. Lancet, 2016, vol. 387, no. 10028, pp. 1657-1671. DOI: 10.1016/S0140-6736(15)00728-X.

7. Bonafe L., Cormier-Daire V., Hall C., Lachman R., Mortier G., Mundlos S., Nishimura G., Sangiorgi L., Savarirayan R., Sillence D., Spranger J., Superti-Furga A., Warman M., Unger S. Nosology and classification of genetic skeletal disorders: 2015 revision. Am. J. Med. Genet. A, 2015 , vol. 167A, no. 12, pp. 2869-2892. DOI: 10.1002/ajmg.a.37365.

8. Marini J.C., Forlino A., Bächinger H.P., Bishop N.J., Byers P.H., Paepe A., Fassier F., Fratzl-Zelman N., Kozloff K.M., Krakow D., Montpetit K., Semler O. Osteogenesis imperfecta. Nat. Rev. Dis. Primers, 2017, vol. 3, pp. 17052. DOI: 10.1038/nrdp.2017.52.

9. Van Dijk F.S., Sillence D.O. Osteogenesis imperfecta: clinical diagnosis, nomenclature and severity assessment. Am. J. Med. Genet. A, 2014, vol. 164A, no. 6, pp. 1470-1481. DOI: 10.1002/ajmg.a.36545.

10. Rodriguez Celin M., Kruger K.M., Caudill A., Nagamani S.C.S.; Brittle Bone Disorders Consortium (BBDC); Linked Clinical Research Centers (LCRC); Harris G.F., Smith P.A. A Multicenter Study of Intramedullary Rodding in Osteogenesis Imperfecta. JB JS Open Access, 2020, vol. 5, no. 3, pp. e20.00031. DOI: 10.2106/JBJS.OA.20.00031.

11. Bregou Bourgeois A., Aubry-Rozier B., Bonafé L., Laurent-Applegate L., Pioletti D.P., Zambelli P.Y. Osteogenesis imperfecta: from diagnosis and multidisciplinary treatment to future perspectives. Swiss Med. Wkly., 2016, vol. 146, pp. w14322. DOI: 10.4414/smw.2016.14322.

12. Ruck J., Dahan-Oliel N., Montpetit K., Rauch F., Fassier F. Fassier-Duval femoral rodding in children with osteogenesis imperfecta receiving bisphosphonates: functional outcomes at one year. J. Child. Orthop., 2011, vol. 5, no. 3, pp. 217-224. DOI: 10.1007/s11832-011-0341-7.

13. Weintrob J.C. Orthotic management for children with osteogenesis imperfecta. Connect. Tissue Res., 1995 , vol. 31, no. 4, pp. S41-S43. DOI: $10.3109 / 03008209509116832$.

14. Montpetit K., Palomo T., Glorieux F.H., Fassier F., Rauch F. Multidisciplinary Treatment of Severe Osteogenesis Imperfecta: Functional Outcomes at Skeletal Maturity. Arch. Phys. Med. Rehabil., 2015, vol. 96, no. 10, pp. 1834-1839. DOI: 10.1016/j.apmr.2015.06.006.

15. Folkestad L., Hald J.D., Ersbøll A.K., Gram J., Hermann A.P., Langdahl B., Abrahamsen B., Brixen K. Fracture Rates and Fracture Sites in Patients With Osteogenesis Imperfecta: A Nationwide Register-Based Cohort Study. J. Bone Miner. Res., 2017, vol. 32, no. 1, pp. 125-134. DOI: 10.1002/ jbmr.2920.

16. Georgescu I., Gavriliu Ș., Nepaliuc I., Munteanu L., Țiripa I., Ghiță R., Japie E., Hamei S., Dughilă C., Macadon M. Burnei's technique of femoral neck varisation and valgisation by using the intramedullary rod in osteogenesis imperfecta. J. Med. Life, 2014, vol. 7, no. 4, pp. 493-498.

17. Sinikumpu J.J., Ojaniemi M., Lehenkari P., Serlo W. Severe osteogenesis imperfecta Type-III and its challenging treatment in newborn and preschool children. A systematic review. Injury, 2015, vol. 46, no. 8, pp. 1440-1446. DOI: 10.1016/j.injury.2015.04.021.

18. Violas P., Mary P. Ostéogenèse imparfaite: place du traitement chirurgical [Imperfecta osteogenesis: interest of surgical treatment]. Arch. Pediatr., 2008, vol. 15, no. 5, pp. 794-796. (in French) DOI: 10.1016/S0929-693X(08)71914-6.

19. Sterian A., Balanescu R., Barbilian A., Tevanov I., Carp M., Nahoi C., Barbu M., Ulici A. Early telescopic rod osteosynthesis for Osteogenesis Imperfecta patients. J. Med. Life, 2015, vol. 8, no. 4, pp. 544-547.

20. Fritz J.M., Guan Y., Wang M., Smith P.A., Harris G.F. A fracture risk assessment model of the femur in children with osteogenesis imperfecta (OI) during gait. Med. Eng. Phys., 2009, vol. 31, no. 9, pp. 1043-1048. DOI: 10.1016/j.medengphy.2009.06.010.

21. Fritz J.M., Guan Y., Wang M., Smith P.A., Harris G.F. Muscle force sensitivity of a finite element fracture risk assessment model in osteogenesis imperfecta - biomed 2009. Biomed. Sci. Instrum., 2009, vol. 45, pp. 316-321.

22. Caouette C., Rauch F., Villemure I., Arnoux P.J., Gdalevitch M., Veilleux L.N., Heng J.L., Aubin C.É. Biomechanical analysis of fracture risk associated with tibia deformity in children with osteogenesis imperfecta: a finite element analysis. J. Musculoskelet. Neuronal Interact., 2014, vol. 14, no. 2, pp. 205-212.

23. Ashby E., Montpetit K., Hamdy R.C., Fassier F. Functional Outcome of Humeral Rodding in Children With Osteogenesis Imperfecta. J. Pediatr. Orthop., 2018, vol. 38, no. 1, pp. 49-53. DOI: 10.1097/BPO.0000000000000729.

24. Laron D., Pandya N.K. Advances in the orthopedic management of osteogenesis imperfecta. Orthop. Clin. North Am., 2013, vol. 44, no. 4, pp. 565573. DOI: 10.1016/j.ocl.2013.06.010.

25. Boutaud B., Laville J.M. L'embrochage centro-médullaire coulissant dans l'ostéogenèse imparfaite: Quatorze cas avec un recul moyen de 8 ans. [Elastic sliding central medullary nailing with osteogenesis imperfecta. Fourteen cases at eight years follow-up]. Rev. Chir. Orthop. Reparatrice Appar. Mot., 2004, vol. 90, no. 4, pp. 304-311. (in French) 
26. Birke O., Davies N., Latimer M., Little D.G., Bellemore M. Experience with the Fassier-Duval telescopic rod: first 24 consecutive cases with a minimum of 1-year follow-up. J. Pediatr. Orthop., 2011, vol. 31, no. 4, pp. 458-464. DOI: 10.1097/BPO.0b013e31821bfb50.

27. Popkov D., Popkov A., Mingazov E. Use of sliding transphyseal flexible intramedullary nailing in pediatric osteogenesis imperfecta patients. Acta Orthop. Belg., 2019, vol. 85, no. 1, pp. 1-11.

28. Popkov D., Dolganova T., Mingazov E., Dolganov D., Kobyzev A. Combined technique of titanium telescopic rods and external fixation in osteogenesis imperfecta patients: First 12 consecutive cases. J. Orthop., 2020, vol. 22, pp. 316-325. DOI: 10.1016/j.jor.2020.05.017.

29. Oberc A., Sułko J. Limitations in Use of Elastic Stable Intramedullary Nailing (ESIN) in Children with Disorders of Bone Mineralization. Ortop. Traumatol. Rehabil., 2020, vol. 22, no. 2, pp. 77-83. DOI: 10.5604/01.3001.0014.1154.

30. Spahn K.M., Mickel T., Carry P.M., Brazell C.J., Whalen K., Georgopoulos G., Miller N.H. Fassier-Duval Rods are Associated With Superior Probability of Survival Compared With Static Implants in a Cohort of Children With Osteogenesis Imperfecta Deformities. J. Pediatr. Orthop., 2019, vol. 39, no. 5, pp. e392-e396. DOI: 10.1097/BPO.0000000000001324.

31. Enright W.J., Noonan K.J. Bone plating in patients with type III osteogenesis imperfecta: results and complications. Iowa Orthop. J. 2006. Vol. 26. P. 37-40.

32. Esposito P., Plotkin H. Surgical treatment of osteogenesis imperfecta: current concepts. Curr. Opin. Pediatr., 2008 , vol. 20 , no. 1, pp. 52-57. DOI: 10.1097/MOP.0b013e3282f35f03.

33. Fassier F., Glorieux F. Osteogeneis imperfecta in the child. Cahiers d'enseignement de la SOFCOT. Paris, Expansion Scientifique Française, 1999, pp. 235-252.

34. Dogba M.J., Rauch F., Wong T., Ruck J., Glorieux F.H., Bedos C. From pediatric to adult care: strategic evaluation of a transition program for patients with osteogenesis imperfecta. BMC Health Serv. Res., 2014, vol. 14, pp. 489. DOI: 10.1186/s12913-014-0489-1.

35. Rauch F., Glorieux F.H. Osteogenesis imperfecta. Lancet, 2004, vol. 363, no. 9418, pp. 1377-1385. DOI: 10.1016/S0140-6736(04)16051-0.

36. Zeitlin L., Fassier F., Glorieux F.H. Modern approach to children with osteogenesis imperfecta. J. Pediatr. Orthop. B, 2003 , vol. 12 , no. 2, pp. 77-87. DOI: 10.1097/01.bpb.0000049567.52224.fa.

37. Fassier F., Sardar Z., Aarabi M., Odent T., Haque T., Hamdy R. Results and complications of a surgical technique for correction of coxa vara in children with osteopenic bones. J. Pediatr. Orthop., 2008, vol. 28, no. 8, pp. 799-805. DOI: 10.1097/BPO.0b013e31818e19b7.

38. Aarabi M., Rauch F., Hamdy R.C., Fassier F. High prevalence of coxa vara in patients with severe osteogenesis imperfecta. J. Pediatr. Orthop., 2006, vol. 26, no. 1, pp. 24-28. DOI: 10.1097/01.bpo.0000189007.55174.7c.

39. Fassier F. Fassier-Duval Telescopic System: How I Do It? J. Pediatr. Orthop., 2017, vol. 37, no. Suppl. 2, pp. S48-S51. DOI: 10.1097/ BPO.0000000000001024.

40. Sułko J., Oberc A. Advantages and Complications Following Fassier-Duval Intramedullary Rodding in Children. Pilot Study. Ortop. Traumatol. Rehabil., 2015, vol. 17, no. 5, pp. 523-530. DOI: 10.5604/15093492.1186830.

41. Nicolaou N., Bowe J.D., Wilkinson J.M., Fernandes J.A., Bell M.J. Use of the Sheffield telescopic intramedullary rod system for the management of osteogenesis imperfecta: clinical outcomes at an average follow-up of nineteen years. J. Bone Joint Surg. Am., 2011, vol. 93, no. 21, pp. 1994-2000. DOI: $10.2106 / J B J S . J .01893$.

42. Shin C.H., Lee D.J., Yoo W.J., Choi I.H., Cho T.J. Dual interlocking telescopic rod provides effective tibial stabilization in children with osteogenesis imperfecta. Clin. Orthop. Relat. Res., 2018, vol. 476, no. 11, pp. 2238-2246. DOI: 10.1097/CORR.0000000000000429.

43. Rosemberg D.L., Goiano E.O., Akkari M., Santili C. Effects of a telescopic intramedullary rod for treating patients with osteogenesis imperfecta of the femur. J. Child. Orthop., 2018, vol. 12, no. 1, pp. 97-103. DOI: 10.1302/1863-2548.12.170009.

44. Mingazov E.R., Gofman F.F., Popkov A.V., Aranovich A.M., Gubin A.V., Popkov D.A. Pervyi opyt primeneniia titanovogo teleskopicheskogo sterzhnia pri korrektsii deformatsii konechnostei u detei s nesovershennym osteogenezom [First use experience with titanium telescopic rod in pediatric limb deformity correction in osteogenesis imperfecta]. Genij Ortopedii, 2019, vol. 25, no. 3, pp. $297-303$.

45. Lascombes P. Flexible intramedullary nailing in children. The Nancy University Manual. Berlin, Heidelberg, Springer-Verlag, 2010 , XVIII, 317 p.

46. Metaizeau J.P. L'embrochage centro-médullaire coulissant. Application au traitement des formes graves d'ostéogénèse imparfaite [Sliding centro-medullary nailing. Application to the treatment of severe forms of osteogenesis imperfecta]. Chir. Pediatr., 1987, vol. 28, no. 4-5, pp. 240-243. (in French)

47. Mingazov E.R., Popkov A.V., Kononovich N.A., Aranovich A.M., Popkov D.A. Rezultaty primeneniia intramedulliarnogo transfizarnogo elastichnogo armirovaniia u patsientov s tiazhelymi formami nesovershennogo osteogeneza [Results of using transphyseal elastic intramedullary nailing in patients with severe types of osteogenesis imperfecta]. Genij Ortopedii, 2016, no. 4, pp. 6-16.

48. Langlais T., Pannier S., De Tienda M., Dukan R., Finidori G., Glorion C, Péjin Z. 'In-Out-In' K-wires sliding in severe tibial deformities of osteogenesis imperfecta: a technical note. J. Pediatr. Orthop. B, 2021, vol. 30, no. 3, pp. 257-263. DOI: 10.1097/BPB.0000000000000785.

49. Saldanha K.A., Saleh M., Bell M.J., Fernandes J.A. Limb lengthening and correction of deformity in the lower limbs of children with osteogenesis imperfecta. J. Bone Joint Surg. Br., 2004, vol. 86, no. 2, pp. 259-265. DOI: 10.1302/0301-620x.86b2.14393.

50. Popkov A., Dučić S., Lazović M., Lascombes P., Popkov D. Limb lengthening and deformity correction in children with abnormal bone. Injury, 2019, vol. 50, no. Suppl. 1, pp. S79-S86. DOI: 10.1016/j.injury.2019.03.045.

51. Joseph B., Rebello G., Chandra Kant B. The choice of intramedullary devices for the femur and the tibia in osteogenesis imperfecta. J. Pediatr. Orthop. B, 2005, vol. 14, no. 5, pp. 311-319. DOI: 10.1097/01202412-200509000-00001.

52. Azzam K.A., Rush E.T., Burke B.R., Nabower A.M., Esposito P.W. Mid-term Results of Femoral and Tibial Osteotomies and Fassier-Duval Nailing in Children With Osteogenesis Imperfecta. J. Pediatr. Orthop., 2018, vol. 38, no. 6, pp. 331-336. DOI: 10.1097/BPO.0000000000000824.

53. Fassier F., Esposito P., Sponsellor P., Smith P., Sussman M., Sundberg S., Ruck-Gibis J., Haque T. Multicenter radiological assessment of the FassierDuval femoral rodding. Proceedings of the Annual Meeting of the Pediatric Orthopaedic Society of North America (POSNA). California, San Diego, May 2-6, 2006.

54. Fassier F., Addar A., Jiang F., Marwan Y., Algarni N., Montpetit K., Hamdy R. Fassier-Duval rodding in Osteogenesis Imperfecta: Long-term results. POSNA Annual meeting, Charlotte NC, May 15-18, 2019.

55. Marafioti R.L., Westin G.W. Elongating intramedullary rods in the treatment of osteogenesis imperfecta. J. Bone Joint Surg. Am., 1977, vol. 59, no. 4, pp. 467-472.

56. El-Adl G., Khalil M.A., Enan A., Mostafa M.F., El-Lakkany M.R. Telescoping versus non-telescoping rods in the treatment of osteogenesis imperfecta. Acta Orthop. Belg., 2009, vol. 75, no. 2, pp. 200-208.

57. Cho T.J., Choi I.H., Chung C.Y., Yoo W.J., Lee K.S., Lee D.Y. Interlocking telescopic rod for patients with osteogenesis imperfecta. J. Bone Joint Surg. Am., 2007, vol. 89, no. 5, pp. 1028-1035. DOI: 10.2106/JBJS.F.00814.

58. Cox I., Al Mouazzen L., Bleibleh S., Moldovan R., Bintcliffe F., Bache C.E., Thomas S. Combined two-centre experience of single-entry telescopic rods identifies characteristic modes of failure. Bone Joint J., 2020, vol. 102-B, no. 8, pp. 1048-1055. DOI: 10.1302/0301-620X.102B8.BJJ-2020-0131.R1.

59. Munns C.F., Rauch F., Zeitlin L., Fassier F., Glorieux F.H. Delayed osteotomy but not fracture healing in pediatric osteogenesis imperfecta patients receiving pamidronate. J. Bone Miner. Res., 2004, vol. 19, no. 11, pp. 1779-1786. DOI: 10.1359/JBMR.040814.

60. Holmes K., Gralla J., Brazell C., Carry P., Tong S., Miller N.H., Georgopoulos G. Fassier-Duval Rod Failure: Is It Related to Positioning in the Distal Epiphysis? J. Pediatr. Orthop., 2020, vol. 40, no. 8, pp. 448-452. DOI: 10.1097/BPO.0000000000001513.

61. Esposito P., Plotkin H. Surgical treatment of osteogenesis imperfecta: current concepts. Curr. Opin. Pediatr., 2008, vol. 20, no. 1, pp. 52-57. DOI: 10.1097/ MOP.0b013e3282f35f03.

62. Bilsel N., Beyzadeoglu T., Kafadar A. Application of Bailey-Dubow rods in the treatment of Osteogenesis Imperfecta. Eur. J. Orthop. Surg. Traumatol., 2005, vol. 10, pp. 183-187.

63. Engelbert R.H., Uiterwaal C.S., Gulmans V.A., Pruijs H., Helders P.J. Osteogenesis imperfecta in childhood: prognosis for walking. J. Pediatr., 2000, vol. 137, no. 3, pp. 397-402. DOI: 10.1067/mpd.2000.107892.

64. Bailey R.W., Dubow H.I. Evolution of the concept of an extensible nail accomodating to normal longitudinal bone growth: clinical considerations and implications. Clin. Orthop. Relat. Res., 1981, no. 159, pp. 157-170. 
65. Kong H., Sabharwal S. Fixator-augmented flexible intramedullary nailing for osteopenic femoral shaft fractures in children. J. Pediatr. Orthop. B, 2016, vol. 25, no. 1, pp. 11-16. DOI: 10.1097/BPB.0000000000000237.

66. Cho T.J., Lee K., Oh C.W., Park M.S., Yoo W.J., Choi I.H. Locking plate placement with unicortical screw fixation adjunctive to intramedullary rodding in long bones of patients with osteogenesis imperfecta. J. Bone Joint Surg. Am., 2015, vol. 97, no. 9, pp. 733-737. DOI: 10.2106/JBJS.N.01185.

67. Franzone J.M., Kruse R.W. Intramedullary nailing with supplemental plate and screw fixation of long bones of patients with osteogenesis imperfecta: operative technique and preliminary results. J. Pediatr. Orthop. B, 2018, vol. 27, no. 4, pp. 344-349. DOI: 10.1097/BPB.0000000000000405.

68. Charnas L.R., Marini J.C. Neurologic profile in osteogenesis imperfecta. Connect. Tissue Res., 1995, vol. 31, no. 4, pp. S23-S26. DOI: $10.3109 / 03008209509116828$.

69. Charnas L.R., Marini J.C. Communicating hydrocephalus, basilar invagination, and other neurologic features in osteogenesis imperfecta. Neurology, 1993, vol. 43, no. 12, pp. 2603-2608. DOI: 10.1212/wnl.43.12.2603.

70. Sasaki-Adams D., Kulkarni A., Rutka J., Dirks P., Taylor M., Drake J.M. Neurosurgical implications of osteogenesis imperfecta in children. Report of 4 cases. J. Neurosurg. Pediatr., 2008, vol. 1, no. 3, pp. 229-236. DOI: 10.3171/PED/2008/1/3/229.

71. Makhdom A.M., Kishta W., Saran N., Azouz M., Fassier F. Are Fassier-Duval rods at risk of migration in patients undergoing spine magnetic resonance imaging? J. Pediatr. Orthop., 2015, vol. 35, no. 3, pp. 323-327. DOI: 10.1097/BPO.0000000000000256.

72. Roberts T.T., Cepela D.J., Uhl R.L., Lozman J. Orthopaedic considerations for the adult with osteogenesis imperfecta. J. Am. Acad. Orthop. Surg., 2016, vol. 24, no. 5, pp. 298-308. DOI: 10.5435/JAAOS-D-15-00275.

73. Gil J.A., DeFroda S.F., Sindhu K., Cruz A.I. Jr., Daniels A.H. Challenges of fracture management for adults with osteogenesis imperfecta. Orthopedics, 2017, vol. 40, no. 1, pp. e17-e22. DOI: 10.3928/01477447-20161006-04.

74. Bishop N.J., Walsh J.S. Osteogenesis imperfecta in adults. J. Clin. Invest., 2014, vol. 124, no. 2, pp. 476-477. DOI: 10.1172/JCI74230.

75. Orwoll E.S., Shapiro J., Veith S., Wang Y., Lapidus J., Vanek C., Reeder J.L., Keaveny T.M., Lee D.C., Mullins M.A., Nagamani S.C., Lee B. Evaluation of teriparatide treatment in adults with osteogenesis imperfecta. J. Clin. Invest., 2014, vol. 124, no. 2, pp. 491-498. DOI: 10.1172/JCI71101.

76. Dwan K., Phillipi C.A., Steiner R.D., Basel D. Bisphosphonate therapy for osteogenesis imperfecta. Cochrane Database Syst. Rev., 2016, vol. 10, no. 10, pp. CD005088. DOI: 10.1002/14651858.CD005088.pub4.

77. Hald J.D., Evangelou E., Langdahl B.L., Ralston S.H. Bisphosphonates for the prevention of fractures in osteogenesis imperfecta: meta-analysis of placebocontrolled trials. J. Bone Miner. Res., 2015, vol. 30, no. 5, pp. 929-933. DOI: 10.1002/jbmr.2410.

78. Rijks E.B., Bongers B.C., Vlemmix M.J., Boot A.M., van Dijk A.T., Sakkers R.J., van Brussel M. Efficacy and Safety of Bisphosphonate Therapy in Children with Osteogenesis Imperfecta: A Systematic Review. Horm. Res. Paediatr., 2015, vol. 84, no. 1, pp. 26-42. DOI: 10.1159/000381713.

79. Glorieux F.H., Bishop N.J., Plotkin H., Chabot G., Lanoue G., Travers R. Cyclic administration of pamidronate in children with severe osteogenesis imperfecta. N. Engl. J. Med., 1998, vol. 339, no. 14, pp. 947-952. DOI: 10.1056/NEJM199810013391402.

80. Shane E., Burr D., Abrahamsen B., Adler R.A., Brown T.D., Cheung A.M., Cosman F., Curtis J.R., Dell R., Dempster D.W., Ebeling P.R., Einhorn T.A., Genant H.K., Geusens P., Klaushofer K., Lane J.M., McKiernan F., McKinney R., Ng A., Nieves J., O'Keefe R., Papapoulos S., Howe T.S., van der Meulen M.C., Weinstein R.S., Whyte M.P. Atypical subtrochanteric and diaphyseal femoral fractures: second report of a task force of the American Society for Bone and Mineral Research. J. Bone Miner. Res., 2014, vol. 29, no. 1, pp. 1-23. DOI: 10.1002/jbmr.1998.

81. Schilcher J., Koeppen V., Ranstam J., Skripitz R., Michaëlsson K., Aspenberg P. Atypical femoral fractures are a separate entity, characterized by highly specific radiographic features. A comparison of 59 cases and 218 controls. Bone, 2013, vol. 52, no. 1, pp. 389-392. DOI: 10.1016/i.bone.2012.10.016.

82. Nicolaou N., Agrawal Y., Padman M., Fernandes J.A., Bell M.J. Changing pattern of femoral fractures in osteogenesis imperfecta with prolonged use of bisphosphonates. J. Child. Orthop., 2012, vol. 6, no. 1, pp. 21-27. DOI: 10.1007/s11832-011-0380-0.

83. Anam E.A., Rauch F., Glorieux F.H., Fassier F., Hamdy R. Osteotomy healing in children with osteogenesis imperfecta receiving bisphosphonate treatment. J. Bone Miner. Res., 2015, vol. 30, no. 8, pp. 1362-1368. DOI: 10.1002/jbmr.2486.

84. Persiani P., Pesce M.V., Martini L., Ranaldi F.M., D'Eufemia P., Zambrano A., Celli M., Villani C. Intraoperative bleeding in patients with osteogenesis imperfecta type III treated by Fassier-Duval femoral rodding: analysis of risk factors. J. Pediatr. Orthop. B, 2018, vol. 27, no. 4, pp. 338-343. DOI: 10.1097/ BPB.0000000000000483.

Received: 14.04.2021

\section{Information about the authors:}

1. Dmitry A. Popkov, M.D., Ph.D., Professor of RAS, correspondent member French Academy of Medical Sciences, Ilizarov National Medical Research Centre for Traumatology and Orthopedics, Kurgan, Russian Federation, Email: dpopkov@mail.ru

2. Eduard R. Mingazov, M.D., Ilizarov National Medical Research Centre for Traumatology and Orthopedics, Kurgan, Russian Federation, Email: ed.dobryak@gmail.com

3. Alexander V. Gubin, M.D., Ph.D., National Medical Research Center of Traumatology and Orthopedics n.a. N.N. Priorov, Moscow, Russian Federation, Email: alexander@gubin.spb.ru

4. Nikita S. Gvozdev,

Ilizarov National Medical Research Centre for Traumatology and Orthopedics, Kurgan, Russian Federation, Email: gvozdev_n.s@mail.ru

5. Anna M. Aranovich, M.D., Ph.D., Professor,

Ilizarov National Medical Research Centre for Traumatology and Orthopedics, Kurgan, Russian Federation, Email: aranovich_anna@mail.ru

6. Alexander L. Semyonov,

Novosibirsk Research Institute of Traumatology and Orthopaedics N.a. Ya.l. Tsivyan, Novosibirsk, Russian Federation, Email: semenov152@yandex.ru 